\title{
Mantra Kenduri Matang Puluh Dina Dusun Dadapan Kecamatan Pagak Kabupaten Malang
}

\author{
Randa Dwi Prastyo \\ Maryaeni \\ Bahasa dan Sastra Indonesia, Universitas Negeri Malang
}

\begin{abstract}
Abstrak
Penelitian ini bertujuan untuk mengkaji sastra lisan berupa mantra berdasarkan konteks dan teks yang ada pada masyarakat dusun Dadapan. Melalui teori Albert b. Lord sebagai acuan utama dapat dipahami bahwa untuk mengkaji sebuah sastra lisan berupa mantra perlu melihat konteks yang mendasari lahirnya sebuah mantra. untuk itu diperlukan konteks performance yang mendasari munculnya teks mantra. Transmisi, komposisi dan formula teks mantra merupakan kajian teks bahwa teks mantra akan tetap eksis ketika ada transmisi dan komposisi sehingga dapat diketahui formula yang dipakai penutur. Berdasarkan hal tersebut muncul fungsi mantra dalam ritual kenduri bagi masyarakat dusun Dadapan baik fungsi Individu maupun sosial.
\end{abstract}

Kata Kunci: mantra; sastra lisan; matang puluh dina

\begin{abstract}
This study aims to examine spells, based on context and text, that exist in the people of Dadapan village. Through Albert's theory $b$. Lord as the main reference can be understood that to study an oral literature in the form of a mantra need to see the context that underlies the birth of a mantra. For this reason, the context of performance that underlies the emergence of the mantra text. Transmission, composition and formula of spell text is a text study that the spell text will still exist when there is transmission and composition so that the formula used by the speaker can be known. Based on this spell function appears in ritual ritual for Dadapan villagers both individual and social functions.
\end{abstract}

Keywords: mantra, oral literature; matang puluh dina 


\section{PENDAHULUAN}

Indonesia adalah negara yang kaya akan kebudayaan dengan keanekaragaman budaya di setiap daerah. Dari masing-masing kebudayaan daerah yang dimiliki, bangsa Indonesia memiliki karakteristik yang unik dan berbeda-beda antardaerah, khususnya kebudayaan Jawa. Kebudayaan Jawa mempunyai ciri khas yang identik dengan perilaku masyarakat Jawa yang dianut oleh para leluhurnya (Endraswara,2004:2). Salah satu kebudayaan Jawa adalah kegiatan ritual yang berkaitan dengan orang-orang yang sudah meninggal. Berdasarkan kegiatan tersebut muncul kepercayaan tentang makhluk gaib yang dipercaya ikut serta dalam sebuah kegiatan spiritual.

Kegiatan seperti upacara adat yang bersifat individu maupun sosial merupakan salah satu bentuk eksistensi masyarakat sebagai pola pewarisan budaya yang masih kental dilakukan sampai saat ini. Salah satu bentuk kegiatan dalam acara ritual di Jawa tidak terlepas dari mantra. Mantra merupakan salah satu bentuk sastra lisan yang masih eksis. Mantra adalah suatu bentuk sastra lama yang dituturkan oleh orang pintar, dukun atau orang yang dihormati untuk mencapai tujuan tertentu (Amir, 2013:67). Badudu (1984:9) mantra adalah kata-kata yang mengandung kalimat dan kekuatan gaib atau magis dan hanya diucapkan oleh orang-orang tertentu saja seperti dukun atau pawang. Oleh karena itu, mantra merupakan susunan kata yang mengandung kekuatan magis ketika diucapkan dalam setiap acara ritual yang dilakukan oleh orang-orang tertentu atau yang biasa disebut dukun atau pawang. Salah satu kegiatan ritual yang masih eksis dilakukan dengan penggunaan mantra adalah kegiatan ritual kenduri. Kenduri merupakan representasi sejumlah keinginan orang Jawa yang biasanya dilakukan dalam bidang spiritual, khususnya bagi yang melakukan kenduri, tentu memiliki nilai dan alasan tertentu, mengapa mereka masih menjalankan dengan taat (Endraswara, 2004:4). Koentjaraningrat (1976:341) mendeskripsikan kenduri berdasarkan harinya, yaitu a) kenduri surtanah atau geblak, b) kendurinelung dina, c) kenduri mitung dina, d) kenduri matang puluh dina, e) kenduri nyatus, f) kenduri mendak sepisan serta mendak pindo, dan g) kenduri nyewu.

Kehadiran mantra dalam ritual kenduri menarik untuk dikaji karena beberapa alasan. Pertama, mantra masih eksis untuk dibawakan karena terdapat elemen-elemen yang menjadi wadah sebagai sarana pembawaan mantra. Kedua, masih dilafalkan oleh penutur tanpa menggunakan teks tulis, niscaya jika tidak diwariskan mantra akan hilang seiring perkembangan zaman. Ketiga, dukun mengucapkan mantra dengan formula yang diucapkan pada tempat yang berbeda dengan mantra yang sama. Keempat, terdapat fungsi mantra dalam ritual kenduri yang masih dilakukan masyarakat dusun Dadapan.

\section{KAJIAN TEORI}

Untuk menjawab rumusan masalah dalam penelitian ini, peneliti menggunakan teori sastra lisan Albert B. Lord sebagai kerangka landasan teori penelitian. Pada dasarnya, teori sastra lisan Albert B Lord berbeda dengan teori-teori sastra lisan pendahulunya yang cenderung memandang sastra lisan dengan pendekatan tekstual. Albert B Lord menekankan bahwa sastra lisan merupakan suatu peristiwa yang spesifik, artinya pertunjukan sastra lisan sangat terkait dengan konteks berlangsung 
pertunjukan tersebut. Sebuah pertunjukan sastra lisan yang dilakukan pada suatu waktu tertentu dan di wilayah tertentu dengan penutur tertentu akan memiliki struktur pertunjukan yang berbeda dengan suatu pertunjukan yang dilakukan oleh penutur, waktu, dan tempat yang berbeda. Artinya, penelitian ini menggunakan pendekatan kontekstual seperti yang digunakan oleh Albert B Lord dalam melihat materi sastra lisan. Oleh karenanya, untuk memahami aspek kelisanan, meliputi konteks performance, komposisi, transmisi, formula, dan fungsi mantra kenduri, peneliti harus memahami konteks secara keseluruhan terhadap peristiwa pembacaan mantra kenduri tersebut dilakukan.

\section{Konteks Performance}

Konteks performance merupakan sebuah bentuk peristiwa yang melandasi adanya teks untuk ditampilkan ataupun disajikan kepada orang lain. Dalam hal ini, konteks performance merupakan sesuatu yang ditampilkan untuk melahirkan sebuah teks lisan. Artinya, terkandung tiga hal dalam performance, yaitu 1) adanya pelaku kegiatan dan disebut sebagai penyaji, 2) adanya kegiatan yang dilakukan oleh penyaji yang kemudian disebut pertunjukan, dan 3) adanya orang (khalayak) yang menjadi sasaran suatu pertunjukan (pendengar, partisipan atau peserta) (Badrun, 2014:13).

Transmisi, Komposisi, dan Formula Teks Mantra

Transmisi atau pewarisan dan komposisi atau penciptaan merupakan suatu aspek kelisanan yang penting untuk diperhatikan dalam memahami sastra lisan sebagai produk budaya. Finnegan (1996:79) menekankan bahwa transmisi tidak dapat dilepaskan dari konsep memori baik yang bersifat pasif maupun aktif. Transmisi yang bersifat pasif menyebarkan unsur kebudayaann ya secara statis dan tidak berubah. Di lain sisi, transmisi yang aktif cenderung merekontruksi dan mereorganisasi dari pengetahuan sebelumnya dengan cara mengaitkannya dengan kreasi atau melakukan perubahan kembali.

Sementara itu, pada penelitian ini komposisi atau penciptaan dalam teks-teks lisan yang ditampilkan oleh setiap penampil akan memiliki perbedaan mesikpun ditampilkan pada judul yang sama dengan penampil yang sama. Pada penelitian ini komposisi atau penciptaan dalam teks-teks lisan yang ditampilkan oleh setiap penampil akan memiliki perbedaan meskipun ditampilkan pada judul yang sama dengan penampil yang sama. Hal tersebut terjadi karena bergantung pada proses pengkreasian dan kemampuan individu yang dimiliki oleh seorang penampil sastra lisan. Lord (1971:13) menjelaskan bawa proses komposisi atau penciptaan dilakukan pada saat pertunjukan berlangsung. Pada komposisi yang dikemukakan oleh Lord, penutur menggunakan formula untuk mengembangkan sebuah teks. Formula yang dikemukakan oleh Lord (1971:30) adalah kelompok kata yang digunakan berulang-ulang secara teratur dalam kondisi matra yang sama untuk mengungkapkan suatu ide pokok.

\section{Fungsi}

Suatu karya sastra tidak akan dipahami oleh masyarakat tanpa mengetahui fungsi dari karya tersebut. Fungsi yang dimaksud dalam hal ini adalah fungsi sastra lisan di dalam masyarakat kolektif pemilik sastra. Fungsi sastra lisan yang sesuai dengan puisi lisan adalah konsep dikemukakan oleh Danandjaja (1994:49) bahwa 1) sebagai alat 
kendali sosial, 2) alat pendidikan anggota masyarakat, 3) untuk hiburan, 4) untuk memulai suatu permainan, dan 5) untuk menekan dan menganggu orang lain. Sementara itu Hutomo (1991:65-74) menjelaskan bahwa fungsi sastra lisan, yaitu 1) sebagai sistem proyeksi, 2) untuk pengesahan kebudayaan, 3) sebagai alat pemaksa berlakunya norma-norma sosial, 4) sebagai alat pendidikan anak, 5) untuk memberikan suatu jalan yang dibenarkan oleh masyarakat agar dia dapat lebih superior, 6) untuk mencela orang lain, 7) sebagai alat untuk protes ketidakadilan dalam masyarakat, dan 8) untuk melarikan diri dari himpitan hidup atau hiburan semata.

\section{Mantra}

Pengertian mantra dapat diketahui dari berbagai sumber, diantaranya sebagai berikut. Menurut Kamus Besar Bahasa Indonesia (2008:987) menjelaskan bahwa mantra adalah perkataan atau ucapan yang dapat mendatangkan daya gaib. Pengertian tersebut didukung oleh Badudu Mantra adalah katakata yang mengandung kalimat dan kekuatan gaib atau magis dan hanya diucapkan oleh orang-orang tertentu saja seperti dukun atau pawang. Pengertian tentang mantra juga tidak lain dari pada suatu gubahan yang diresapi oleh kepercayaan kepada dunia gaib dan sakti, gubahan bahasa dalam mantra itu mempunyai seni kata yang khas (Nur, 2014:21). Ketelitian dan kecermatan memilih kata, menyusun larik dan menetapkan iramanya sangat diperlukan terutama untuk menimbulkan tenaga gaib (Nur, 2014:21). Maka dari itu, pemakaian mantra benar-benar tidak diperlakukan secara sembarangan. Sejalan dengan Nur, Bharati (2002:3-4) menjelaskan bahwa mantra adalah sekumpulan kata-kata, pikiran, dan doa, tetapi bukan dalam arti "doa" yang biasa digunakan tetapi merupakan penghubung kesadaran bawah kita dengan kesadaran kita yang lebih tinggi, yang disebut Kesadaran Ilahi atau kekuatan-kehidupan Ilahi. Berdasarkan pendapat tersebut menjelaskan bahwa mantra merupakan sekumpulan kata yang memiliki kekuatan magis yang biasa digunakan untuk pada sebuah ritual atau upacara adat untuk keperluan seseorang.

Menurut Waluyo (1995:8) ada beberapa ciri pokok mantra, yaitu 1) pemilihan katakata yang sangat seksama, 2) bunyi-bunyi diusahakan berulang-ulang dengan maksud memperkuat daya sugesti kata, dan 3) banyak dipergunakan kata-kata yang kurang umum digunakan dalamkehidupan sehari-hari dengan maksud memperkuat daya sugesti kata. Jika dibacakan dengan keras, mantra menimbulkan efek bunyi yang bersifat magis, bunyi tersebut diperkuat oleh irama dan mentrum yang biasanya hanya dipahami secara sempurna oleh pawang ahli yang membaca mantra tersebut.

\section{METODE PENELITIAN}

Penelitian ini dirancang menggunakan pendekatan kualitatif. Penelitian kualitatif adalah penelitian yang bermaksud memahami fenomena tentang apa yang dialami subjek penelitian misalnya perilaku, persepsi, motivasi, tindakan dan lain-lain secara holistik dan dengan cara deskripsi dalam bentuk kata-kata dan bahasa, pada suatu konteks khusus yang alamiah dan dengan memanfatkan metode alamiah (Moleong, 2014:6). Penelitian ini dilakukan dengan menggunakan pendekatan etnografi, yaitu mempelajari suatu kebudayaan dengan pengetahuan yang meliputi teknik penelitian dan berbagai macam deskirpsi kebudayaan (Spradley, 2007:13). Dengan 
pendekatan etnografi, manusia sebagai objek yang menghasilkan kebudayaan memakai bahasa yang beragam bentuknya. Oleh karena itu, dalam penelitian ini menggunakan langkah yang dipakai dengan menggunakan pendekatan etnografi.

Dusun Dadapan dipilih sebagai lokasi penelitian karena 1) masyarakat Dusun Dadapan merupakan pemilik sastra lisan berupa mantra, 2) masyarakat Dusun Dadapan merupakan masyarakat turun-temurun yang menghuni Dusun Dadapan sehingga keasliannya belum tercampur oleh masyarkat luar dan mayoritas beragama Hindu sehingga ritualritual dalam agama hindu juga masih banyak dilaksanakan, dan 3) masyarakat dusun Dadapan mempercayai kekuatan mantra untuk memberikan keberkahan agar terhindar dari berbagai bencana, hal tersebut dibuktikan bahwa mantra selalu ikut serta dalam ritual yang ada di dusun Dadapan, khususnya dalam acara ritual kenduri atau selamedhan.

Ada dua jenis data dalampenelitian ini yaitu data utama dan data pelengkap. Data utama pada penelitian ini ada berupa teks lisan yang terkait dengan mantra kenduri. Teks lisan yang dimaksud adalah dalam bentuk kata-kata atau kalimat yang diutarakan oleh penutur mantra saat membacakan mantra dalam ritual kenduri. Data tersebut kemudian direkam kemudian di transkrip oleh peneliti untuk dikaji lebih dalam tentang formula yang dipakai oleh informan. Sementara itu, data pelengkap berupa wawancara yang dilakukan kepada penutur mantra untuk mencari informasi tentang sebuah proses sastra lisan yang ada dan masih dilakukan oleh masyarakat sampai saat ini, sehingga informan dalam hal ini sangat berpengaruh pada data yang diperlukan.
Pengumpulan data yang digunakan pada penelitian ini dilakukan melalui observasi, wawancara, dan dokumentasi. Observarsi dilakukan peneliti dengan mengamati suasana saat pertunjukan kenduri berlangsung khususnya di tempat ritual kenduri dilakukan. Dengan kegiatan tersebut peneliti dapat mengetahui proses sastra lisan yang masih dilakukan saat kegiatan berlangsung di dusun Dadapan. Dengan kegiatan tersebut, peneliti mendapatkan data sastra lisan melalui proses perekaman mantra yang dilafalkan oleh penutur mantra di beberapa tempat yang berbeda dengan penutur yang sama. Data tersebut menjadi acuan dalam mengolah kalimat yang digunakan oleh penutur. Sementara itu, untuk melengkapi data lisan secara alami dilakukan wawancara kepada penutur mantra mulai dari pewarisan sampai penciptaan berlangsung.

Analisis data dilakukan melalui beberapa tahap, yaitu reduksi data, penyajian data, dan upaya penarikan kesimpulan (Miles dan Huberman, 1992:16). 1) reduksi data, mereduksi data berarti merangkum, memilih hal-hal yang pokok, memfokuskan pada hal-hal yang penting, dan mencari polanya, 2) Penyajian data, penyajian data adalah kegiatan menyusun sekumpulan informasi untuk memudahkan penarikan kesimpulan, bentuk penyajian data kualitatif dapat berupa teks naratif, matrik, grafik, jaringan, dan bagan, 3) Kesimpulan, kesimpulan ini bertujuan untuk menjawab fokus yang telah ditentukan.

\section{HASIL PEMBAHASAN}

\section{Konteks Performance}

Pada konteks performance terdapat elemen-elemen yang mendukung lahirnya mantra serta tata urutan kenduri yang 
menunjukan bahwa ada pembawaan mantra yang dilakukan oleh penutur. Kendurimatang puluh dina pada penelitian ini dilakukan dengan melihat konteks situasi saat pertunjukan kenduri berlangsung. Dalam proses kegiatan ini, ada elemen-elemen yang mendukung munculnya teks, yaitu 1) penutur atau pemimpin jalannya ritual (penyaji) sebagai penutur mantra, 2) peserta ritual (partisipan), 3) setting, dan 4) sarana pelengkap ritual (Badrun, 2014:31). Konteks situasi yang digunakan mengacu pada pembentukan teks mantra kenduri matang puluh dina di dusun Dadapan. Elemen-elemen tersebut yang melengkapi prosesi jalannya ritual yang dilakukan saat ritual kenduri.

Setiap elemen dalam ritual kenduri memiliki peran dan menempati posisi yang dimainkan oleh beberapa orang, yaitu penutur mantra sekaligus pemimpin jalannya ritual, 2) peserta sebagai partisipan, dan 3) kelengkapan upacara ritual yang meliputi sesaji dan beberapa alat sebagai pendukung jalannya ritual. Pemimpin atau penutur mantra pada ritual kenduri di dusun Dadapan dilakukan oleh bapak Musidi. Saat ini, bapak Musidi berusia 60 tahun dengan kulit sawo matang, rambut yang sudah mulai putih, memiliki alat ucap yang sempurna, dan memiliki kedudukan sebagai orang yang pernah menjadi pengusir setan saat pertunjukan jaranan. Partisipan yang diundang hadir dalam pertunjukan kenduri baik melaui lisan maupun tulisan tidak ada batasan usia untuk menghadirinya. Berdasarkan penelitian di lapangan, ritual kenduri yang dilakukan dihadiri dari yang masih muda sampai yang paling tua. Memang tidak ada aturan untuk kehadiran peserta dalam ritual kenduri. Biasanya kehadiran partisipan muda karena mewakili seseorang dari keluarganya yang tidak bisa hadir atau berhalangan hadir. Kehadiran partisipan dalam pertunjukkan kenduri merupakan sebuah elemen penting karena teks mantra akan lengkap dengan kesaksian yang diutarakan oleh partisipan meskipun hanya dengan penggunaan kata nggih. $\mathrm{BM}$ : Nggih pangestune dateng panembahan kulo miwah derek kulo planem sepuh sedaya nggih

Partisipan : Nggih

(Data lengkap hasil transkrip mantra ada pada penulis)

Sementara itu, kelengkapan ritual yang turut melengkapi jalannya ritual, baik yang dipakai oleh bapak musidi saat membacakan mantra maupun makanan yang nantinya akan dibagikan kepada partisipan. Alat yang dipakai oleh bapak Musidi sebagai pendukung jalannya ritual, seperti dupa, wadah dupa, dan korek api. Sedangkan, makanan yang dihidangkan berupa nasi, ingkung, dan apem yang mengandung simbol bagi masyarakat Jawa.

Adapun tata urutan dalam ritual kenduri, yaitu Berawal dari partisipan yang hadir dalam setiap acara kenduri, baik penutur maupun partisipan yang hadir menggunakan pakaian formal dan membentuk lingkaran dalam satu latar, Setelah semua partisipan berkumpul dan dirasa sudah mencukupi, kelengkapan ritual seperti hasil alam berupa makanan yang akan didoakan sudah disediakan ditengah-tengah peserta, Ritual kenduri dipimpin oleh bapak Musidi sebagai penutur mantra. Bapak musidi memulai acara dengan diawali mantra awal yang dibaca dengan suara pelan dengan beberapa alat yang dijadikanalat pendukung ritual dari pemilik rumah, kemudian Pembacaan mantra dipimpin oleh bapak Musidi disampaikan langsung secara lisan. 
Nggih pangestune dateng panembahan kulo miwah derek kulo planem sepuh sedaya nggih

Sedaya ingkang sami katuran lan pilenggahan kantosipun (Diah) mriki kang pun sepuh dipun suwun idi pangestunipun ingkang anem dipun suwun tanduripun wilujeng.

Lafal tersebut diucapkan oleh bapak Musidi saat mengawali mantra yang disampaikan. Dari hasil transkrip tersebut dapat dilihat bahwa bapak Musidi menyebutkan "Sedaya ingkang sami katuran lan pilenggahan kantosipun (Diah) mriki kang pun sepuh dipun suwun idi pangestunipun ingkang anem dipun suwun tanduripun wilujeng" artinya "semua yang sudah diberi undangan dan sudah dapat tempat duduk dirumah (Diah) yang sudah tua ingin meminta doa dari yang masih muda yang sudah masih akan tumbuh nantinya" penutur menyampaikan secara langsung tujuan untuk meminta doa baik yang sudah tua maupun muda tanpa melihat teks karena kehadiran partisipan yang hadir dapat dilihat pada saat itu juga. Setelah selesai mantra selesai dirapalkan, makanan yang sudah disajikan dibagi rata dan dimakan bersama peserta yang hadir.

\section{Transmisi, Komposisi, dan Formula Teks Mantra}

Mantra dalam ritual kenduri merupakan produk budaya yang masih dilakukan di dusun Dadapan sampai saat ini. Hal tersebut dikarenakan adanya transmisi dan komposisi (penciptaan) secara lisan yang dilakukan untuk menghasilkan produk budaya, seperti mantra dalam ritual kenduri di dusun Dadapan. Mantra dalam ritual kenduri merupakan sebuah produk budaya berupa sastra lisan karena pengucapannya tanpa teks tertulis. Dalam sebuah ritual kenduri, mantra yang dilafalkan penutur memiliki arti tersendiri saat dilafalkan oleh orang tertentu. Sebagai sebuah produk budaya, keberdaaan sastra lisan tidak dapat dipisahkan dari aspek terciptanya sastra lisan hingga keberlangsungan hidupnya (eksistensi) di masyarakat yang merupakan hal penting untuk diperhatikan (Pratiwi, 2017:86). Pada transmisi teks mantra terdapat kriteria yang dipilih untuk menjadi seorang pewaris mantra seng pertama kudu niat, terus kudu wong lanang soale genduren e mesti wong lanang lak gak tumon a ono wong wedok, terus kudu nduwe mantu tujuan e ben iso diterusne nang mantune misal anak e wedok, la lek wes kabeh iku mau terusane seng ate belajar kudu teko terus nang acara kenduri kabeh gak mek kematian tok, mulai nyadran, slametan liyane kabeh kudu teko, dan seng penting iki kudu sehat akal e.

(Data lengkap hasil transkrip mantra ada pada penulis)

Kriteria yang dipakai penutur ketika mewariskan sebuah teks mantra kenduri kepada generasi penerusnya, yaitu punya keinginan atau niat, harus laki-laki, memiliki menantu yang kemungkinan bisa diwakilkan kepada generasi berikutnya, pewaris berikutnya selalu ikut dalam ritual kenduri, dan kondisi mental yang sehat

Kriteria tersebut dibuat tidak baku oleh seorang penutur. Akan tetapi, meskipun kriteria tersebut tidak baku seorang pewaris mantra minimal harus sesuai dengan kriteria tersebut karena bisa dipercaya jika kriteria tersebut masih belum ditemukan niscaya akan mendapat musibah. 
Syarat e misal ekoyok kowe umpamane wes apal terus mbesok lek sampek dorong nduwe anakk nduwe mantu ora oleh ono bala' e nang awak e dewe yo bala e iku mbuh aku dewe yo ora ngerti lah iki ono seng wes ngalami yo jare wong wong iku Munaji iku durung nduwe mantu wes methik la akhir e oleh kedowo umur mulakne ora oleh nah iku jare wong tuwek mbiyen yo mek ngunu kuwi, yo saiki aku wes uwapal lihai tapi durung nduwe anak opo maneh durung nduwe mantu gak kenek ujub ujub seng paribasan e di dep wong akeh

Seorang pewaris mantra meskipun sudah memahami dan menghafal seluruh mantra tetapi kalau belum mempunyai menantu akan celaka di suatu hari nanti seperti yang dialami oleh seseorang di dusun Dadapan bernama bapak Munaji yang meninggal secara tiba-tiba dikarenakan mencoba mempraktikan bacaan mantra tapi belum memenuhi satu kriteria. Akan tetapi kematian tersebut juga masih menjadi misteri kebenarannya karena pewarisan mantra tersebut atau hal lain.

Proses untuk menjadi pewaris mantra kenduri memerlukan waktu yang relatif lama. Finnegan (1996:79) menekankan bahwa transmisi tidak dapat dilepaskan dari konsep memori baik yang bersifat pasif maupun aktif. Akan tetapi, hal itu bergantung pada kemampuan calon pewaris. Calon pewaris harus belajar menguasai formula dengan sebanyak-banyaknya. Artinya, calon pewaris harus banyak mendengarkan dan menyaksikan pertunjukan penutur senior yang dilakukan dimanapun. Dengan demikian, akan terlihat seberapa besar kemampuan yang dimiliki oleh pewaris mantra saat beberapa kali penampilan yang ditampilkannya sebagai penutur berikutnya.

Sementara itu, Sebuah mantra bisa dilafalkan dengan susunan kata yang cukup banyak karena seorang penutur mampu untuk menkomposisikannya. komposisi (penciptaan) mantra kenduri di dusun Dadapan matang puluh dina merupakan suatu proses kemampuan seorang penutur dalam menciptakan teks mantra. Lord (1971:13) menjelaskan bawa proses komposisi atau penciptaan dilakukan pada saat pertunjukan berlangsung. Proses penciptaan yang dilakukan oleh bapak Musidi merupakan proses penciptaan yang dilakukan saat keberlangsungan ritual kenduri. Hal tersebut juga akan dilakukan saat ritual kenduri lainnya.

Wektu genduren aku ngrapalne ujubujub iku ndelok seng disajekne yopo karo keperluane. Lah teko kunu baru iso ndelok seng bakal diucapne nang masyarakat iku opo ae kan sesuai karo sajen e. Ora ngarang paribasan nang kunu ono tumpeng, yo tumpeng mau disampekno kebutuhan e gawe ngene, terus ono inkung, ono jenang abang, ono sekul suci yo ngunu iku wes, misale gak ono apeme, yo apemora disebutno. Tapi apem iku ono simbol e dewe.

Bapak Musidi melafalkan mantra saat performance sesuai dengan sesaji yang ditampilkan saat pertunjukan berlangsung akan memunculkan kelompok kata yang akan dirangkai disebut sebagai formula

Dalam hal pengkomposisiani, seorang penutur sastra lisan hanya mengandalkan daya ingatnya sebagai pemandu yang bekerja dalam sistem ingatannya (Pratiwi, 2017:101). Hal tersebut merupakan pengkomposisian yang dilakukan oleh bapak Musidi saat performance 
berlangsung karena menggunakan sistem formula dalam ingatannya tanpa harus menghafalnya secara keseluruhan.

Formula yang dimaksudkan Lord (1971:30) menjelaskan bahwa formula adalah kelompok kata yang digunakan berulang-ulang secara teratur dalam kondisi matra yang sama untuk mengungkapkan suatu ide pokok.

M1 : 5) bilih sak katuran maleh sekul suci lan sari kangge ngabekteni Gusti njeng nabi Rasullullah kecal sak garwo seputro sekabat ngalih ngumah rusman dateng mbok dewi pertiwi dipun ngabekteni wageto nglayungaken wilujeng lan ngabulaken

M2 : 10) katuraken maleh sekul suci lan sari ugi kang kintunaken dateng sukmo lan dosipun bu Timah ngaweruhi Gustijeng nabi Rasullullah kecal sak garwo seputro sekabat ngalih ngumah rusman dateng mbok dewi pertiwi dipun ngabekteni

M3 : sakkaturaken maleh sekul suci lan sari kang kintunaken dateng sukmo langgengipun pak Gimin ngaweruhi Gusti njeng nabi Rasulullah kecal sak garwo seputro sekabat ngalih ngumah rusman dateng mbok dewi pertimah dipun ngabekteni

(Data lengkap hasil transkrip mantra ada pada penulis)

Kelompok kata "sekul suci lan sari kangge ngabekteni Gustinjeng nabi Rasullullah kecal sak garwo seputro sekabat ngalih ngumah rusman dateng mbok dewi pertiwi" pada M1 terdapat di baris kelima, pada M2 terdapat di baris ke-10, dan M3 terdapat di baris keempat.

Sementara itu, terdapat beberapa variasi polanya oleh bapak Musidi menggunakan mantra yang sama di tempat yang berbeda.
(1) Sedaya ingkang sami kakung lan pilenggahan kantosipun (Diah) mriki kang pun sepuh dipun suwun idi pangestunipun ingkang anem dipun suwun tanduripun wilujeng. M1

Sedaya ingkang sami kakung lan pilenggahan ngrantosi mrikikang pun sepuh dipun suwun idi pangestunipun ingkang anem dipun suwun tanduripun wilujeng. M2 Sedaya ingkang sami katuran pilenggahan ngrantosi mriki ing griyane pak (Marsuki) ingkang sepuh dipun suwun idi pangestunipun ngikral aken dipun suwun tanduripun wilujeng. M3

(Data lengkap hasil transkrip mantra ada pada penulis)

Terdapat formula mantra baris pertama, ditemukan bahwa kalimat yang diulang berada pada posisi yang sama, dengan variasi pada beberapa kata, yaitu: kantosi (1), ngrantosi (2), dan ngrantosi (3) yang terletak pada awal kalimat. Variasi kata ngikralaken hanya terletak pada formula mantra (3), sementara pada formula mantra (1) dan (2) tidak ditemukan variasi kata tersebut. Saputra (2007:27) bahwa di dalam formula terdapat berbagai variasi pola. Hal tersebut terjadi dikarenakan mantra yang dilafalkan pada tempat yang berbeda meskipun dengan tema mantra yang sama oleh penutur yang sama.

\section{FUNGSI MANTRA KENDURI}

Ritual kenduri yang biasanya dilaksanakan oleh masyarakat dusun Dadapan merupakan suatu kegiatan upacara untuk menyampaikan maksud melalui doa-doa yang dilafalkan oleh penutur tertentu. Dengan kegiatan tersebut, mantra dalam kenduri Imemiliki fungsi yang dapat dibagi menjadi fungsi individu dan fungsi sosial. Fungsi individu terkait dengan 
kegunaannya bagi penutur melalui mantra tersebut dan fungsi sosial terkait dengan masyarakat sosial dusun Dadapan.

Fungsi Individu berhubungan dengan penggunaan mantra bagi individu, yaitu mendekatkan diri kepada Tuhan melalui mantra. Bapak Musidi sebagai penutur mantra menjelaskan bahwa mantra yang dipelajarinya merupakan salah satu akses untuk menyampaikan doa melalui kenduri dari ciptaanNya kembali ke Sang Pencipta.

Aku sinau ngene iki ora mergo dikongkon karo wong, teko niate awal iku tujuan e gawe opo. La ak sinau ujub-ujub salah sijine yo gawe roso syukur. Carane lewat ngujubne genduren. La hasil seng dibagi-bagi iku lak yo teko gawenane seng Kuoso la mbalik e yo nang sing Kuoso. Liwat coro iki kepinginan ku gawe nyedek nang seng gawe urip.

(Data lengkap hasil transkrip mantra ada pada penulis)

Dengan pelafalan mantra dalam ritual kenduri, penutur akan mengingat kepada Sang Kuasa bahwa hasil alam maupun kehidupan merupakan ciptaanNya yang kemudian suatu hari nanti akan kembali kepada Sang Pencipta.

Selain sebagai fungsi individu kegiatan ritual kenduri dari aspek fungsi sosial adalah kegunaan ritual kenduri bagi masyarakat pemiliknya, yaitu untuk meningkatkan solidaritas kelompok dan sebagai alat kendali sosial. dalam hal meningkatkan solidaritas kelompok, pada setiap kegiatan ritual kenduri banyak partisipan yang duduk secara bersebelahan tanpa terlihat sekat yang membentuk satu latar. Setiap partisipan berkumpul menjadi satu untuk berdoa bersama ketika ada saudara yang berduka cita. Ketika ritual kenduri sudah dilakukan, saat makan bersama setiap masyarakat biasanya akan membicarakan sesuatu baik untuk memajukan warga maupun mempererat tali silaturahmi. Dengan kegiatan seperti ini, dapat dilihat solidaritas masyarakat di dusun Dadapan masih sangat kuat dalam setiap ritual yang dilakukan, khususnya ketika ritual kenduri.

Sementara itu, ritual kenduri sebagai alat kendali sosial yang masih dilakukan sampai saat ini di dusun Dadapan. Hal tersebut dikarenakan sebagian masyarakat percaya bahwa ritual kenduri sebagai alat pengendalian sosial.

Tapi yo repot karo arek nom saiki diomongi kadang-kadang yo ra dirungokne, jane aku iki yo cerewet ono wong genduren seng tuwekk tuwek podo silo arek nom e metongkrong iku yo tak aru arui yo lek ora kepentut sepisan pindo ne yo ra sopan.

(Data lengkap hasil transkrip mantra ada pada penulis)

Sebagai alat pengendali sosial terbukti dari adanya himbauan kepada generasi muda untuk lebih belajar sopan santun ketika berhadapan dengan banyak orang khususnya dalam ritual kenduri. Dengan demikian setiap generasi muda yang ikut sebagai perwakilan dalam ritual kenduri akan mengerti bersosial di masyarakat. Hal tersebut sesuai dengan fungsi dari salah satu puisi lisan, yaitu sebagai alat kendali sosial(Danandjaja, 2002:49).

\section{KESIMPULAN}

Hasil penelitian menunjukkan bahwa untuk mengkaji sebuah mantra terdapat konteks performance yang mendasari bahwa teks hadir di masyarkat melalui ritual kenduri 
matang puluh dina. Pada konteks performance terdapat elemen-elemen yang mendukung munculnya teks mantra yang dibacakan secara lisan oleh penutur mantra dan dihadirkan di depan partisipan sebagai saksi bahwa mantra tersebut disetujui oleh masyarakat dusun Dadapan serta tata cara urutan kenduri yang mempelihatkan bahwa mantra diucapkan saat semua elemen sudah terkumpul. Dalam kepercayaan masyarakat setempat, ritual kenduri matang puluh dina dimaksudkan sebagai upaya untuk mempermudah perjalanan roh orang yang didoakan menuju ke alam kubur dengan mantra yang diucapkan oleh penutur.

Untuk bisa menampilkan hal tersebut seseorang yang dianggap penutur merupakan pilihan masyarakat yang dipercaya untuk melafalkan mantra dan seorang generasi penerus sebagai pewaris mantra sebelumnya. Sebagai seorang penutur mantra yang mampu membacakan teks mantra adapun transmisi yang dilakukan untuk mememperoleh sebuah mantra melalui kriteria dan syarat yang dilakukan oleh penutur terdahulu. Saat performance kemampuan penutur akan dilihat saat pertunjukan berlangsung dengan penciptaan melalui formula yang dipakai pada saat itu juga. Formula yang dipakai penutur dapat dilihat dari hasil transkrip yang menunjukan kata yang sealalu diulang dan berbagai variasi pola yang digunakan oleh penutur yang sama dengan mantra yang sama di tempat yang berbeda. Saat pelafalan mantra dalam pertunjukan ritual kenduri matang puluh dina ditemukan sebelas variasi pola formula yang dipakai oleh penutur.
Sementara itu, kehadiran ritual kenduri di dusun Dadapan memiliki fungsi bagi masyarakat kolektifnya, yaitu baik fungsi individu maupun fungsi sosial. Fungsi individu berkaitan dengan penutur mantra yang bertujuan untuk lebih mendekatkan diri kepada Sang Pencipta pada saat acara tersebut. Hal ini diyakini karena dengan adanya ritual kenduri matang puluh dina mengingatkan penutur bahwa setiap manusia akan kembali kepada Sang Pencipta dan penggunaan sejumlah formula yang dianggap memiliki kekuatan gaib. Di sisi lain, fungsi sosial berkaitan dengan ritual kenduri adalah untuk meningkatkan solidaritas kelompok, khususnya di dusun Dadapan agar masyarakat memiliki kekompakan maupun jiwa manusiawi untuk menolong sesama manusia. Selain hal tersebut, pertunjukan ritual kenduri juga sebagai alat kendali sosial yang bertujuan agar masyarakat ada hubungan baik dari partisipan untuk saling mendoakan maupun dari pemohon yang memberikan sesaji.

Berdasarkan simpulan tersebut, perlu dilakukan penelitian yang terkait dengan mantra secara lebih mendalam karena dari hasil wawancara peneliti yang menunjukan fakta yang memprihatinkan, bahwa sampai saat ini belum ada generasi penerus yang ingin menjadi penutur mantra. Dengan tidak dilakukan transmisi dan komposisi, niscaya teks mantra akan musnah. Kehadiran peneliti saat meneliti di lapangan menjadi daya tarik bagi penutur untuk menjadikan peneliti sebagai penutur mantra berikutnya. Akan tetapi hal tersebut harus sesuai dengan syarat pewarisan yang ditentukan oleh penutur sebelumnya. 


\section{DAFTAR RUJUKAN}

Amir, A. 2013. Sastra Lisan Indonesia. Yogyakarta: Penerbit Andi

Badrun, Ahmad. 2014. Struktur, Konsep Pertunjukkan, Proses Peciptaan, dan Fungsi. Jakarta: Lengge

Badudu, J.S. dkk.1984. Perkembangan Puisi Indonesia Tahun 20-an Hingga 40-an. Jakarta: Pusat Pembinaan dan Pengembangan Bahasa Departemen Pendidikan dan Kebudayaan

Danandjaja, James. 1994. Folklor Indonesia: Ilmu gosip, dongeng, dan lain-lain. Jakarta: PT Pustaka Utama Grafiti.

Danandjaja, James. 2002. Folklor Indonesia. Jakarta: Pusaka Utama Grafiti.

Endraswara, Suwardi. 2004. Mistik Kejawen: Sinkretisme, Simbolisme dan Sufisme dalam Budaya Spiritual Jawa. Jogjakarta. NARASI

Finnegan, Ruth. 1996. Oral Tradtions and The Verbal Art. London

Hutomo, S.S. 1991. Mutiara Yang Terlupakan: Pengantar Studi Sastra Lisan. Jawa Timur:Hiski
Koentjaraningrat. 1976. Manusia dan Kebudayaan di Indonesia. Djambatan Sapdodadi.

Lord, Albert. B.. 1971. The Singer Of Tales. London. Harvard

Miles, M. B dan Huberman. 1984. Analisis Data Kualitatif. Jakarta: Universitas Indonesia Press.

Moleong, Lexy J. 2014. Metodologi Penelitian Kualitatif. Bandung: Remaja Rosda Karya Nur, A. Herlina. 2014. Mantra Tolaki. Sulawesi Tenggara: Kementrian Pendidikan dan Kebudayaan.

Pratiwi, Yuni. dkk. 2017. Penelitian Sastra Lisan Kontekstual: PerformanceCentered-Approach. Malang

Saputra, Heru S.P. 2007. Memuja Mantra: Sabuk Mangir dan Jaran Goyang Masyarakat Suku Using Banyuwangi. LKiS Spradley, James P. 2007. Metode Etnografi. Yogyakarta: Tiara Wacana.

Tim Penyusun. 2008. Kamus Besar Bahasa Indonesia. Jakarta: Departemen Pendidikan Nasional

Waluyo, J. herman. 1995. Teori dan Apresiasi Puisi. Jakarta: Erlangga 